\title{
Cordycepin prevents oxidative stress-induced inhibition of osteogenesis
}

\author{
Feng Wang ${ }^{1, *}$, Peipei Yinn ${ }^{1, *}$, Ye Lu ${ }^{1}$, Zubin Zhou ${ }^{1}$, Chaolai Jiang ${ }^{1}$, Yingjie Liu ${ }^{1}$ and \\ Xiaowei $\mathbf{Y u}^{1}$ \\ ${ }^{1}$ Department of Orthopaedic Surgery, Shanghai Jiao Tong University Affiliated Sixth People's Hospital, Shanghai, China \\ * These authors contributed equally to this work and should be considered as equal first coauthors \\ Correspondence to: Xiaowei Yu, email: yuxw@sjtu.edu.cn \\ Keywords: cordycepin, osteoprotection, oxidative stress, Wnt pathway, Pathology Section \\ Received: August 06, $2015 \quad$ Accepted: September 28, $2015 \quad$ Published: October 10, 2015
}

This is an open-access article distributed under the terms of the Creative Commons Attribution License, which permits unrestricted use, distribution, and reproduction in any medium, provided the original author and source are credited.

\section{ABSTRACT}

Oxidative stress is known to be involved in impairment of osteogenesis and age-related osteoporosis. Cordycepin is one of the major bioactive components of Cordyceps militaris that has been shown to exert antioxidant and anti-inflammatory activities. However, there are few reports available regarding the effects of cordycepin on osteogenesis and the underlying mechanism. In this study, we investigated the potential osteoprotective effects of cordycepin and its mechanism systematically using both in vitro model as well as in vivo mouse models. We discovered that hydrogen peroxide $\left(\mathrm{H}_{2} \mathrm{O}_{2}\right)$ induced inhibition of osteogenesis which was rescued by cordycepin treatment in human bone marrow mesenchymal stem cells (BM-MSCs). Cordycepin exerted its protective effects partially by increasing or decreasing expression of osteogenic and osteoclastogenesis marker genes. Treatment with cordycepin increased Wnt-related genes' expression whereas supplementation of Wnt pathway inhibitor reversed its protective effects. In addition, administration of cordycepin promoted osteogenic differentiation of BM-MSCs by reducing oxidative stress in both ovariectomized and aged animal models. Taken together, these results support the protective effects of cordycepin on oxidative stress induced inhibition of osteogenesis by activation of Wnt pathway.

\section{INTRODUCTION}

Oxidative stress is described as an imbalance between excess production of ROS and free radicals (FR) and insufficient antioxidant system function [1]. Several pieces of evidence have suggested a link between oxidative stress, bone formation and osteogenic differentiation [2]. It has been reported that oxidative stress impairs bone mineral density in aged human subjects and reduces osteogenic differentiation of murine preosteoblastic and bone marrow-derived stromal cell lines which can be restored by antioxidants [3-5], suggesting that oxidative stress plays an important role in bone injury and age-related osteoporosis. It is well documented that ROS regulates various signaling pathways involved in osteogenesis, including Wnt/ $\beta$-catenin, MAPK and
Hedgehog pathways [2].

It is now known that human bone marrow (BM) harbors a rare population of mesenchymal stem cells (MSC) which retains ability to self-renew and to differentiate into multiple tissues [6]. MSCs exhibit immunomodulatory properties, thereby emerging as attractive candidates for various therapeutic applications [7], especially regenerative medicine. It has been shown that allogeneic bone marrow transplantation in children with defective osteogenesis allowed engraftment of functional donor MSCs, resulting in increased bone marrow density [8]. Therefore, BM-MSCs are believed to hold great therapeutic potential in fracture injury and bone regeneration [9].

Cordycepin, a derivative of the nucleoside adenosine, is one of the major bioactive components of 
Cordyceps militaris [10]. Cordycepin has been shown to have a variety of biological functions, including antitumor, antiviral, anti-oxidant, and anti-inflammatory activities [11-14]. Importantly, cordycepin has been shown to attenuate age-related oxidative stress and enhances antioxidant capacity in rats [10]. It has also been shown to prevent rat hearts from ischemia/reperfusion injury partially by activating antioxidant defense response via upregulation of heme oxygenase (HO-1) expression [15]. However, there are few reports available regarding the effects of cordycepin on osteogenesis and its potential mechanism.

Wnt pathway acts as a fundamental signaling pathway that regulates cell proliferation, cell polarity and cell fate determination during embryonic development and tissue homeostasis [16]. Dysregulation of this pathway has been linked to congenital malformation, cancer, osteoporosis and other diseases [17]. Recently, accumulating evidence showed that activation of canonical Wnt signaling led to enhanced bone density whereas disruption of its activation impaired osteogenesis primarily through regulating its downstream target genes, such as $\beta$-catenin, cyclin D1, etc $[18,19]$.

Ovariectomized (OVX) mice are female mice whose ovaries have been removed. OVX mouse model has been used as a typical experimental model for investigation of postmenopausal osteoporosis due to estrogen deficiency in women. In our study, we investigated the potential osteoprotective effects of cordycepin and the underlying mechanism systematically using BM-MSCs as in vitro model and OVX as well as aged mouse model as in vivo models.

\section{RESULTS}

\section{Effects of $\mathrm{H}_{2} \mathrm{O}_{2}$ and cordycepin treatment on cell viability of human BM-MSC}

We first characterized BM-MSCs by flow cytometry and observed that majority of the cells were $\mathrm{CD} 73^{+}$, $\mathrm{CD}^{+} 0^{+} \mathrm{CD} 105^{+}, \mathrm{CD} 34-$ and $\mathrm{CD} 45^{-}$, which are typical characteristic phenotypes of BM-MSCs (Figure 1a). Oxidative damage was induced by treating BM-MSCs with increasing concentrations of $\mathrm{H}_{2} \mathrm{O}_{2}(0.1,0.2,0.5,1$ and $2 \mathrm{mM}$ ) for 24 hours. $0.2 \mathrm{mM}$ and higher concentrations of $\mathrm{H}_{2} \mathrm{O}_{2}$ significantly decreased cell viability in these cells (Figure 1b). Treatment with cordycepin alone at concentration of $10 \mu \mathrm{g} / \mathrm{mL}$ or lower did not affect cell viability (Figure 1c). Importantly, $5 \mu \mathrm{g} / \mathrm{mL}$ or $10 \mu \mathrm{g} / \mathrm{mL}$ of cordycepin in cells with $0.2 \mathrm{mM} \mathrm{H}_{2} \mathrm{O}_{2}$ exposure increased cell viability compared to cells without cordycepin treatment, indicating that cordycepin can partially inhibit $\mathrm{H}_{2} \mathrm{O}_{2}$ induced cytotoxicity (Figure 1d). Also, the BMMSCs presented healthy growth and the population doubling time was $\sim 64$ hours (Figure S1).
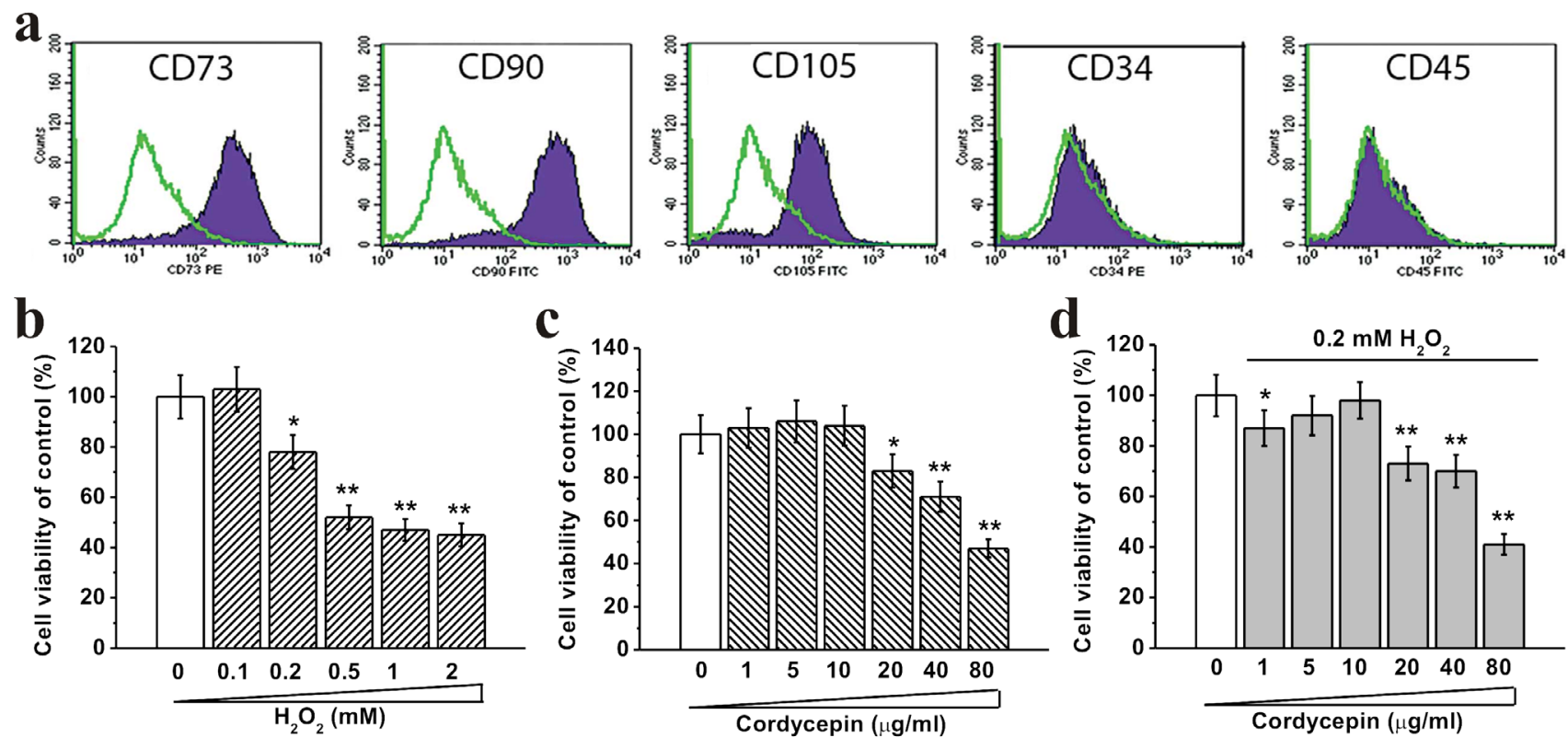

Figure 1: Human BM-MSC viability under different concentrations of $\mathrm{H}_{2} \mathrm{O}_{2}$ and cordycepin treatment at DIV 5. a. Characterization of BM-MSCs by flow cytometry. The majority of the cells are $\mathrm{CD}_{73^{+}}, \mathrm{CD} 90^{+}, \mathrm{CD} 105^{+}, \mathrm{CD}^{-} 4^{-}$and $\mathrm{CD}^{-} 5^{-}$, which are typical characteristic phenotypes of BM-MSCs. Effects of different concentrations of $\mathrm{H}_{2} \mathrm{O}_{2}(0.1,0.2,0.5,1$ and $2 \mathrm{mM})$ exposure for the first 24 hours during the culture. b., different concentrations of cordycepin $(1,5,10,20,40$ and $80 \mu \mathrm{g} / \mathrm{mL})$ without $0.2 \mathrm{mM} \mathrm{H}_{2} \mathrm{O}_{2}$ exposure c. and with $0.2 \mathrm{mM} \mathrm{H}_{2} \mathrm{O}_{2}$ exposure d. on BM-MSC viability, measured by MTT assay. Data were presented as mean \pm S.E.M. $*^{*} p<0.05$ and $* * p<0.01$ versus control. 


\section{Cordycepin protects against $\mathrm{H}_{2} \mathrm{O}_{2}$ induced inhibition of osteogenic differentiation of human $\mathrm{BM}-\mathrm{MSC}$ in vitro}

We investigated protective effects of cordycepin against $\mathrm{H}_{2} \mathrm{O}_{2}$ induced inhibition of osteogenic differentiation by measuring ALP activity and calcium content. $0.2 \mathrm{mM}$ and higher concentrations of $\mathrm{H}_{2} \mathrm{O}_{2}$ or $40 \mu \mathrm{g} / \mathrm{mL}$ and higher concentration of cordycepin alone significantly decreased ALP activity and calcium content whereas $10 \mu \mathrm{g} / \mathrm{mL}$ of cordycepin increased ALP activity and calcium content (Figure $2 \mathrm{a}$ and $2 \mathrm{~b}$ ). Cotreatment of $10 \mu \mathrm{g} / \mathrm{mL}$ of cordycepin reversed $\mathrm{H}_{2} \mathrm{O}_{2}$ induced dysfunction as demonstrated by increased ALP staining, activity and calcium content (Figure 2c-2e). ALP activity and calcium content, which are indicators for early and late osteogenesis, are measured 8 and 16 days after cell culture, respectively. Meanwhile, as an essential transcription factor for osteogenesis, runt-related transcription factor 2 (Runx2) was examined as well. The mRNA levels of Runx2 were inhibited in the presence of $0.2 \mathrm{mM} \mathrm{H}_{2} \mathrm{O}_{2}$, while co-treatment with $10 \mu \mathrm{g} / \mathrm{mL}$ of cordycepin successfully restored the mRNA levels of Runx2 (Figure 2f).

\section{Effects of cordycepin on the expression of osteogenic markers}

Based on the dose-related protective effects of cordycepin above, $10 \mu \mathrm{g} / \mathrm{mL}$ cordycepin was chosen for the following studies. We further evaluated the effects of $10 \mu \mathrm{g} / \mathrm{mL}$ cordycepin on the expression of osteogenic marker genes using RT-PCR. The results showed that the expression of two osteogenic genes, $O P N$ and Collagen $I$, were significantly upregulated in cordycepin treated cells compared to cells treated with $0.2 \mathrm{mM}$ of $\mathrm{H}_{2} \mathrm{O}_{2}$ alone (Figure 3a). Additionally, cordycepin markedly increased the expression of $O P G$ but reduced expression of $R A N K L$ compared to $\mathrm{H}_{2} \mathrm{O}_{2}$ alone treated cells (Figure 3b). $O P G$ inhibits osteoclast differentiation by binding to $R A N K L$. The ratio between mRNA expressions of $O P G$ to $R A N K L$ is usually used as an indicator of osteoclastogenesis inhibition [20]. Therefore, the above results suggest that $10 \mu \mathrm{g} / \mathrm{mL}$ cordycepin enhances osteogenic differentiation partially through promoting expression of osteogenic markers and inhibition of osteoclastogenesis.
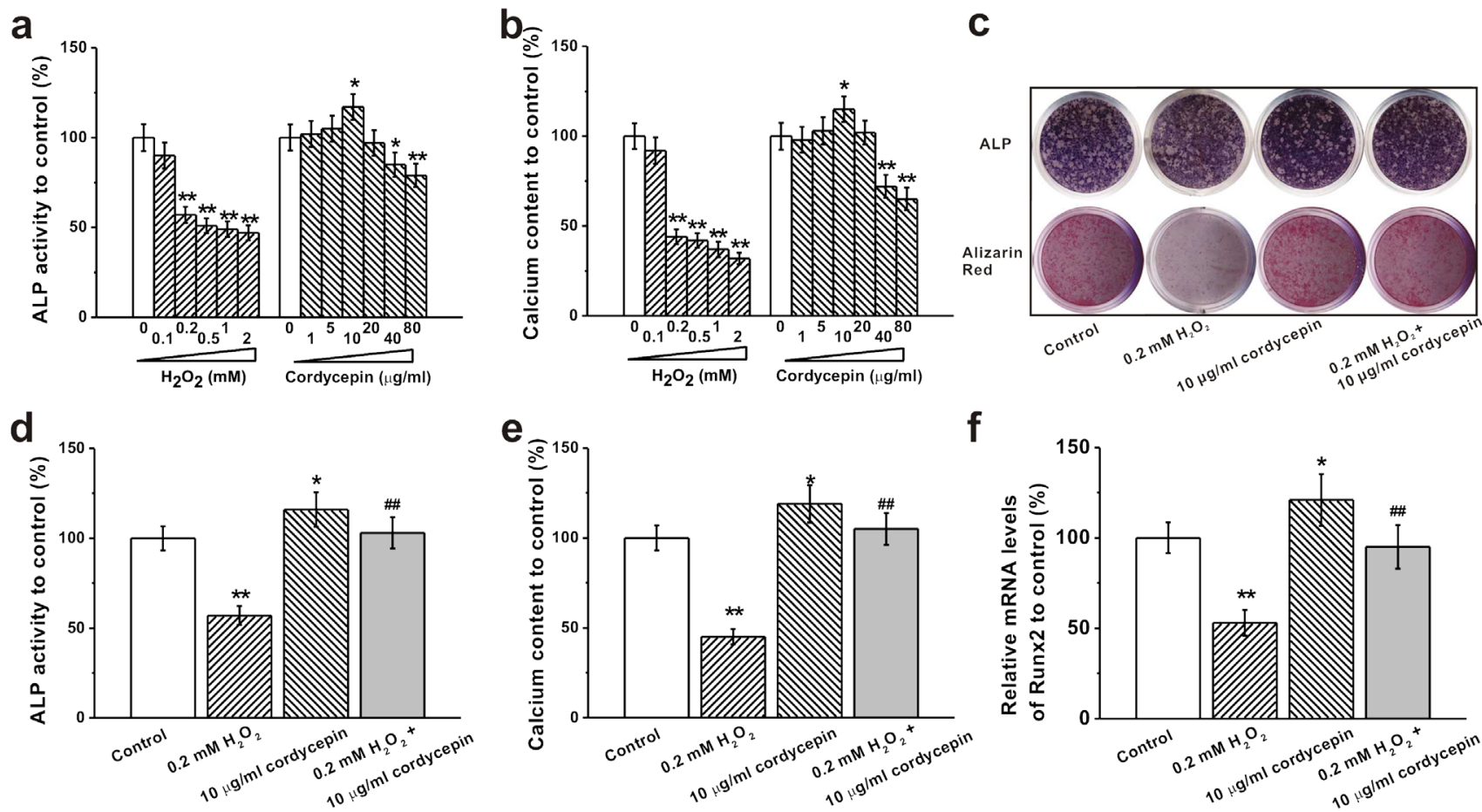

Figure 2: Effects of different concentrations of $\mathrm{H}_{2} \mathrm{O}_{2}(0.1,0.2,0.5,1$ and $2 \mathrm{mM})$ and cordycepin $(1,5,10,20,40$ and 80 $\boldsymbol{\mu g} / \mathbf{m L}$ ) on osteogenic differentiation of human BM-MSCs. The osteogenic differentiation was characterized by ALP activity a. at DIV 8 and calcium content b. at DIV 16. c. Representative images for ALP staining in the cultures at DIV 8 and Alizarin red staining in

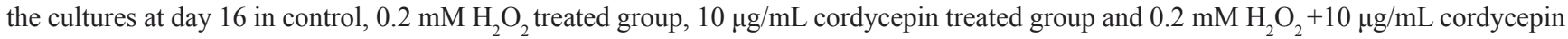
co-treated group. The relative ALP activity d., calcium content e. and mRNA levels of Runx2 f. to control in these four groups in (c). Data were shown as mean \pm S.E.M. ${ }^{*} p<0.05$ and ${ }^{* *} p<0.01$ versus control, $\# \# p<0.01$ versus $0.2 \mathrm{mM} \mathrm{H}_{2} \mathrm{O}_{2}$ treated group. 


\section{Cordycepin exerts anti-oxidant effects}

We next examined whether cordycepin exerted antioxidant effects using DCF fluorescence quantification assay. As shown in the representative photographs of DCF fluorescence as well as the relative DCF quantification, $10 \mu \mathrm{g} / \mathrm{mL}$ cordycepin markedly reduced intracellular ROS levels induced by $\mathrm{H}_{2} \mathrm{O}_{2}$ treatment (Figure 4). Treatment with cordycepin alone did not exhibit dramatic effects on ROS level (Figure 4b).
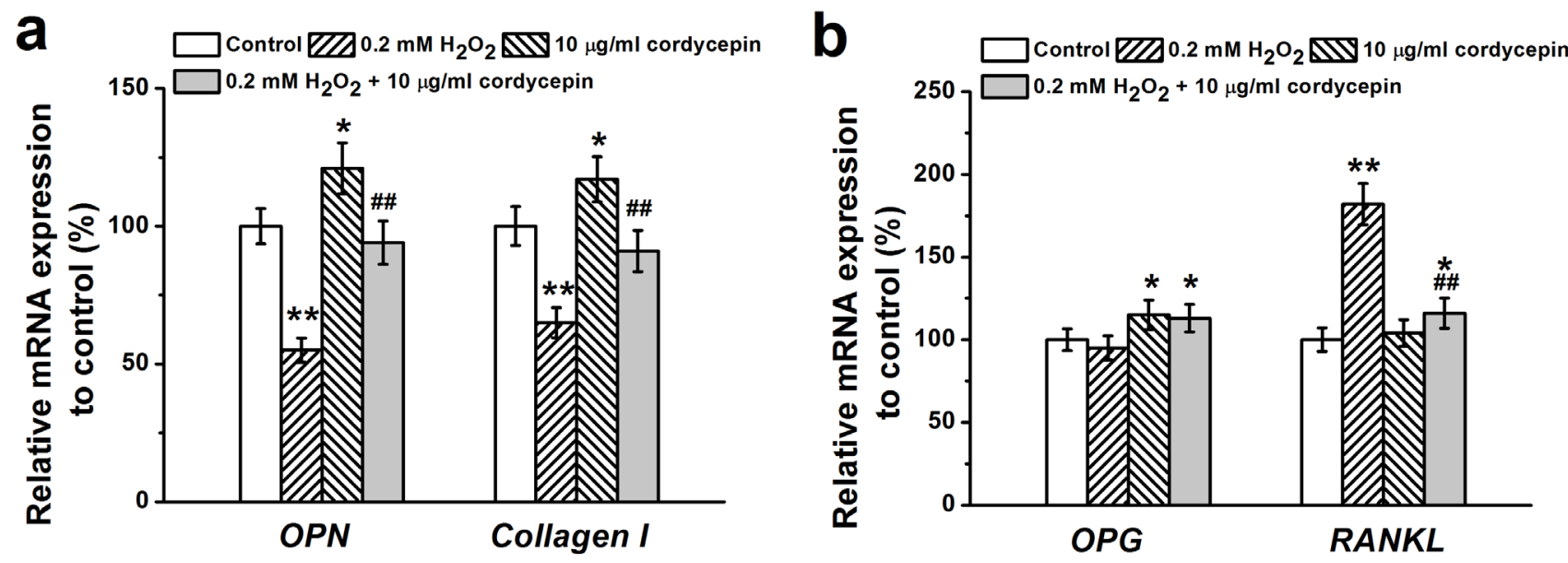

Figure 3: Osteogenic differentiation of human BM-MSCs treated by $0.2 \mathrm{mM} \mathrm{H}_{2} \mathrm{O}_{2}, 10 \mu \mathrm{g} / \mathrm{mL}$ cordycepin and $0.2 \mathrm{mM}$

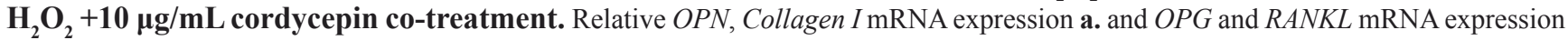
in the experimental groups were characterized by RT-PCR analysis. Gene expression was normalized to GAPDH. Data were shown as mean \pm S.E.M. ${ }^{*} p<0.05$ and ${ }^{* *} p<0.01$ versus control, \#\#p<0.01 versus $0.2 \mathrm{mM} \mathrm{H}_{2} \mathrm{O}_{2}$ treated group.
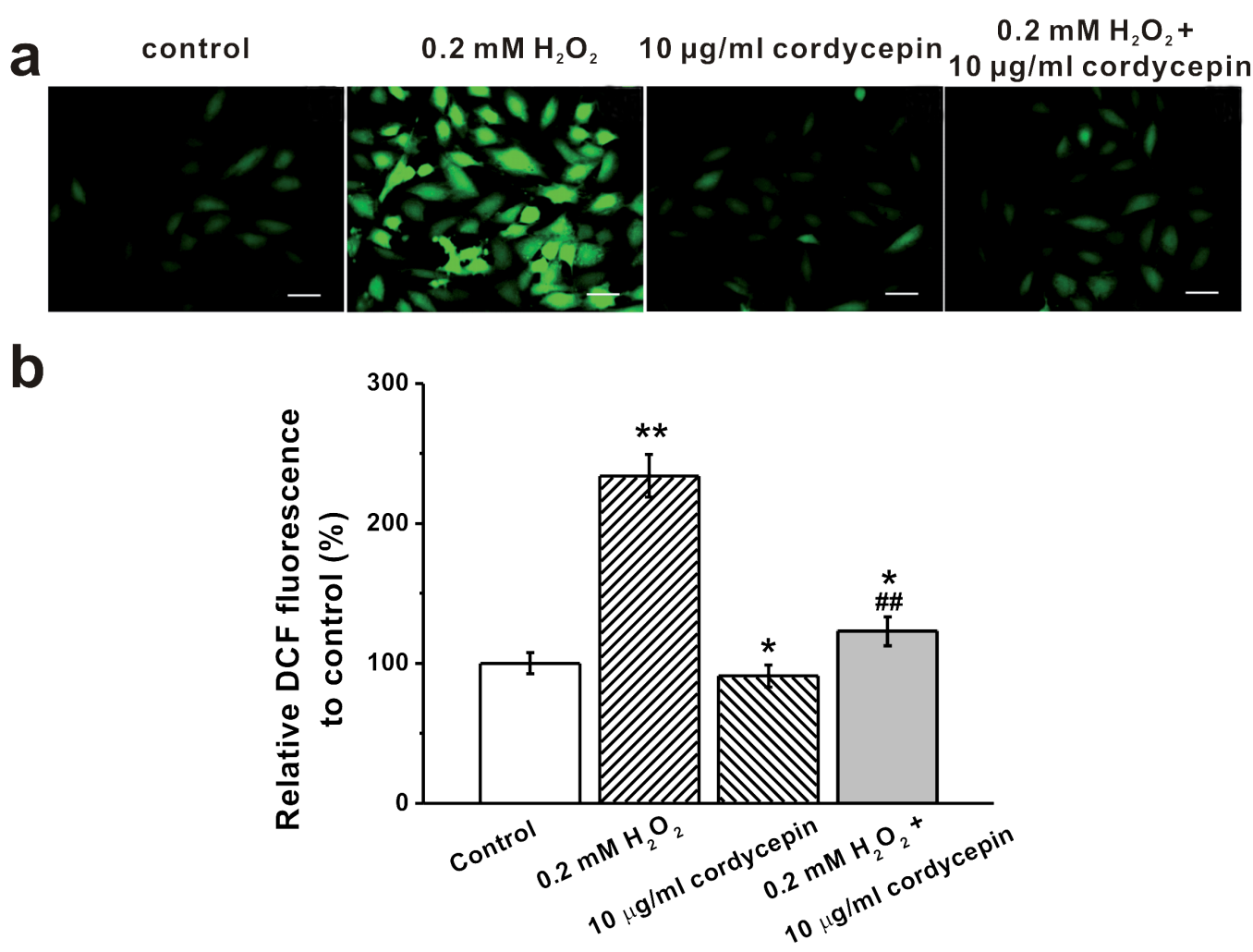

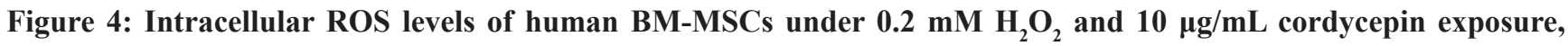
determined by DCF fluorescence. a. Representative photographs of DCF fluorescence in the experimental groups. Scale bar $=10 \mu \mathrm{m}$. b. Relative DCF fluorescence was quantitatively analyzed and expressed as percent units of DCF fluorescence of the control. Data were shown as mean \pm S.E.M. ${ }^{*} p<0.05$ and ${ }^{* *} p<0.01$ versus control, \#\#p $<0.01$ versus $0.2 \mathrm{mM} \mathrm{H}_{2} \mathrm{O}_{2}$ treated group. 
Involvement of Wnt pathway in the osteoprotective effects of cordycepin on human BM-MSCs

It has been reported that ROS regulates signaling cascades implicated in osteogenesis, such as Wnt pathway
[2]. Western Blot analysis showed that $0.2 \mathrm{mM}$ of $\mathrm{H}_{2} \mathrm{O}_{2}$ treatment reduced protein level of Wnt pathway related regulators $\beta$-catenin and cyclin $\mathrm{D} 1$, which was rescued by $10 \mu \mathrm{g} / \mathrm{mL}$ cordycepin co-treatment (Figure $5 \mathrm{a}$ and $5 b)$. Meanwhile, cordycepin successfully reversed the $\mathrm{H}_{2} \mathrm{O}_{2}$-induced inhibition of expression of $\beta$-catenin in the nucleus (Figure $5 \mathrm{c}$ and $5 \mathrm{~d}$ ), implicating the involvement a
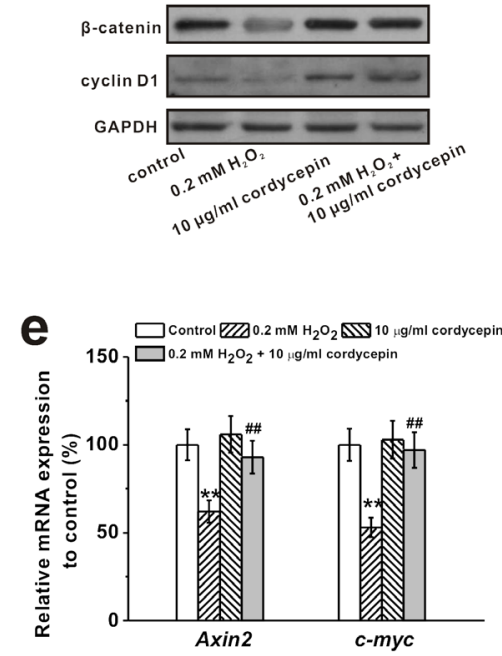

C
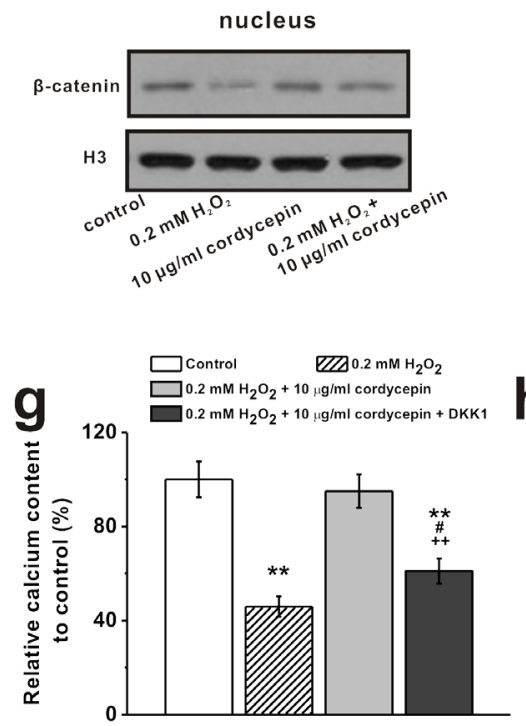

b
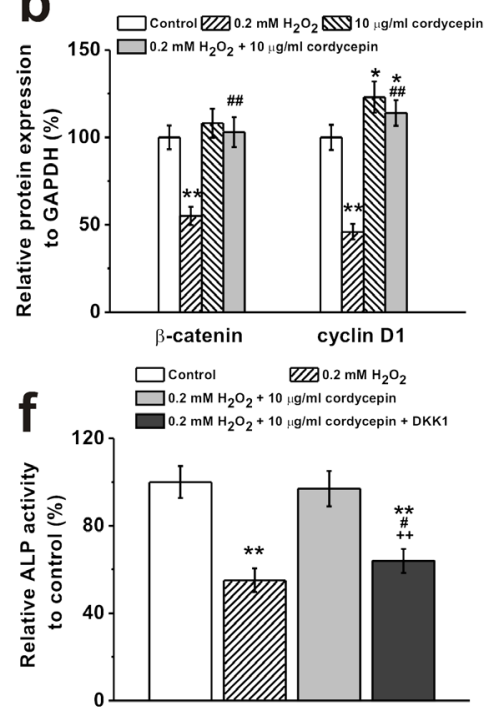

d
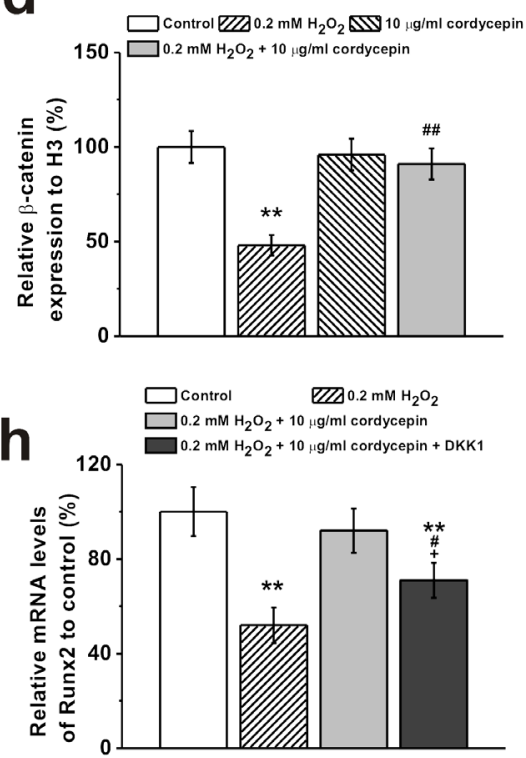

Figure 5: Wnt pathway was involved in the protective effects of cordycepin on the inhibition of osteogenic differentiation of human BM-MSCs induced by $0.2 \mathrm{mM} \mathrm{H}_{2} \mathrm{O}_{2}$. Western blot analysis a. and the relative protein expression $\mathbf{b}$. of Wnt pathwayrelated regulators $\beta$-catenin and cyclin D1 in control, $0.2 \mathrm{mM} \mathrm{H}_{2} \mathrm{O}_{2}$ treated group, $10 \mu \mathrm{g} / \mathrm{mL}$ cordycepin treated group, and $0.2 \mathrm{mM} \mathrm{H}_{2} \mathrm{O}_{2}$ $+10 \mu \mathrm{g} / \mathrm{mL}$ cordycepin co-treated group. c., d. Representative western blot bands of $\beta$-catenin and the relative expression in the nucleus. e. Relative mRNA expression of Axin2 and c-myc in the experimental groups. Wnt pathway inhibitor, DKK-1 $(0.2 \mu \mathrm{g} / \mathrm{ml})$, could greatly depressed the effects of cordycepin on the inhibition of osteogenic differentiation by $\mathrm{H}_{2} \mathrm{O}_{2}$ exposure, as evidenced by ALP activity f., calcium contents $\mathbf{g}$. and Runx2 mRNA expression $\mathbf{h}$. Data were shown as mean \pm S.E.M. ${ }^{*} p<0.05$ and ${ }^{* *} p<0.01$ versus control, $\# p<0.05$ and \#\#p $<0.01$ versus $0.2 \mathrm{mM} \mathrm{H}_{2} \mathrm{O}_{2}$ treated group, $+p<0.05$ and $++p<0.01$ versus $0.2 \mathrm{mM} \mathrm{H}_{2} \mathrm{O}_{2}+10 \mu \mathrm{g} / \mathrm{ml}$ cordycepin co-treated group. 
of Wnt pathway in the protective effects of cordycepin. This was further verified by the results from two other gene markers of Wnt signaling pathway, Axin2 and c-myc. $\mathrm{H}_{2} \mathrm{O}_{2}$ treatment depressed the mRNA levels of both Axin2 and c-myc, while cordycepin co-treatment restored their expressions to control level (Figure 5e). Additionally, supplementation of Wnt pathway inhibitor, DKK1 $(0.2$ $\mu \mathrm{g} / \mathrm{mL})$, reversed the protective effects of cordycepin as demonstrated by the decreased ALP activity, calcium content and Runx2 mRNA levels compared to cordycepin treated cells (Figure 5f, 5g and 5h), further confirming the possible involvement of Wnt pathway.

\section{Cordycepin attenuates oxidative stress in vivo}

Next we investigated effects of cordycepin on oxidative stress in vivo using OVX mouse model and aged mouse model by measuring relative serum MDA levels and GSH levels. OVX or aged mice were injected with either vehicle or increasing concentration of cordycepin $(1,5,10$ and $20 \mathrm{mg} / \mathrm{kg})$. OVX or aged receiving vehicle showed significantly higher MDA levels and lower GSH levels compared with control or young non-treated mice whereas cordycepin administration reversed these effects in a dose-dependent manner (Figure 6). These results suggest that cordycepin can attenuate oxidative stress in vivo.

\section{Effects of cordycepin on in vivo osteogenic differentiation of human BM-MSCs}

To evaluate the effects of cordycepin on in vivo osteogenic differentiation of MSCs, we measured the calcium content in the implantation specimens from OVX and aged mice described above injected with vehicle or increasing concentration of cordycepin $(1,5,10$ and 20
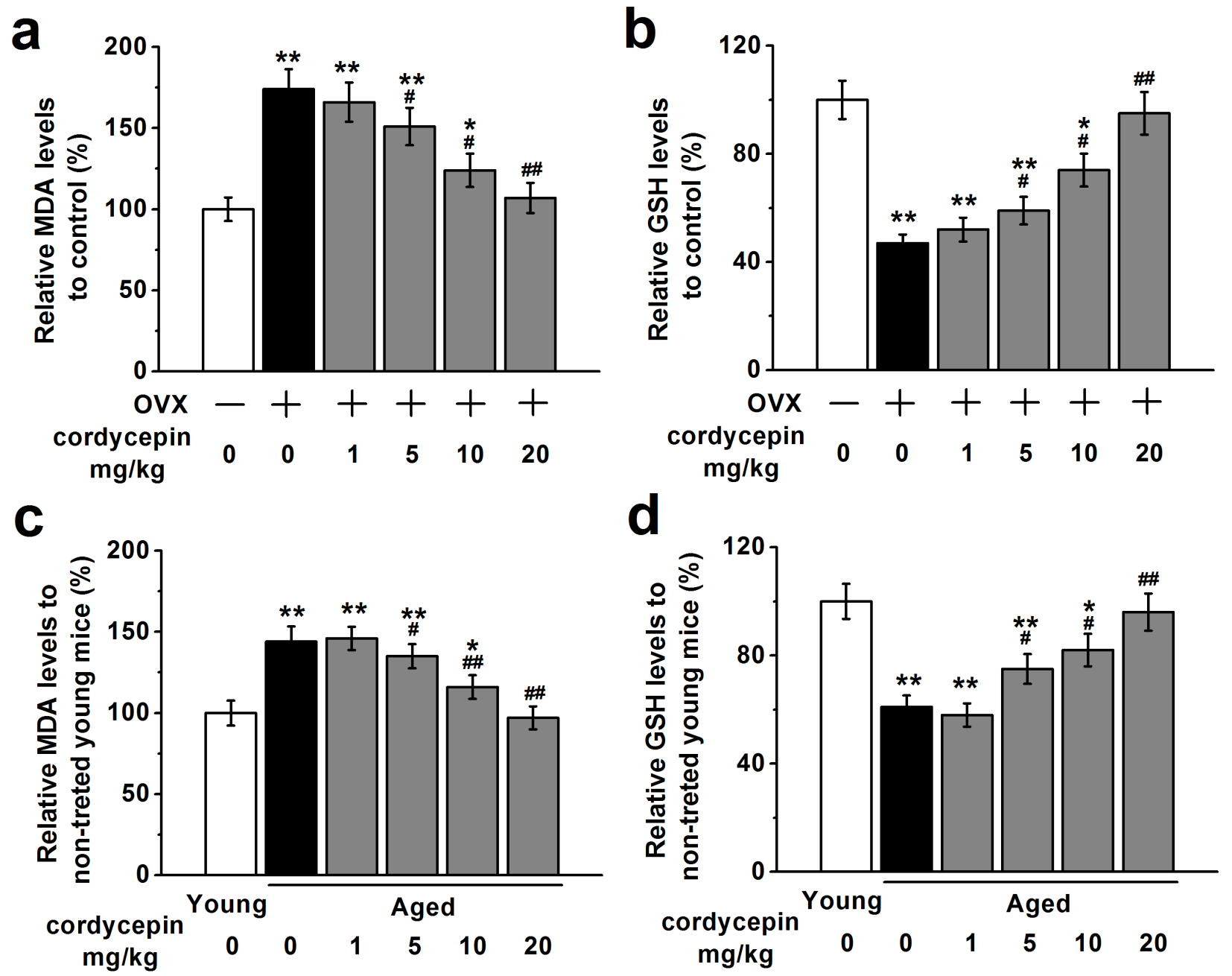

Figure 6: Cordycepin attenuates oxidative stress in ovariectomized a., b. and aged animal models c., d. ( $n=8$ in all groups), measured by relative serum MDA levels and GSH levels. Data were shown as mean \pm S.E.M. ${ }^{*} p<0.05$ and ${ }^{* *} p<0.01$ versus control or non-treated young mice, $\# p<0.05$ and $\# \# p<0.01$ versus OVX group or non-treated aged mice. 
$\mathrm{mg} / \mathrm{kg}$ ). As shown in Figure 7, specimens derived from OVX or aged mice showed decreased calcium content compared to control or young non-treated mice. Treatment with increased concentration of cordycepin increased calcium content in a dose dependent manner, suggesting that cordycepin can promote osteogenesis in vivo.

\section{Cordycepin augments in vivo bone formation induced by BM-MSCs}

To further study the effects of cordycepin on in vivo bone formation induced by BM-MSCs in OVX animal model, H\&E staining and micro-computed tomography (micro-CT) examination were employed in OVX-treated mice. As shown in the H\&E staining images (Figure $8 \mathrm{a})$, the control mice showed normal compactness of the diaphysis and competent trabeculae, while OVX mice showed sparse, uniform thinning of trabeculae. The disappearance and loss of connectivity resulted in bigger intertrabecular spaces. This was obviously improved by MSC treatment, especially when co-treated with cordycepin $(5,10$ and $20 \mathrm{mg} / \mathrm{kg})$. Micro-CT examination was used to detect the bone mass and bone mineral density in the experimental groups (Figure 8b). As shown in Figure $8 \mathrm{c}$ and d, OVX treatment $(n=8)$ induced a significant loss in bone volume and bone mineral density compared to control $(n=8)$. MSC treatment $(n=8)$ significantly increased the bone volume and bone mineral density, while co-treatment with cordycepin at 5, 10 or $20 \mathrm{mg} / \mathrm{kg}$ further greatly improved bone volume and bone mineral density in a dose-dependent manner. These results indicate that cordycepin is able to augment in vivo bone formation induced by MSCs.

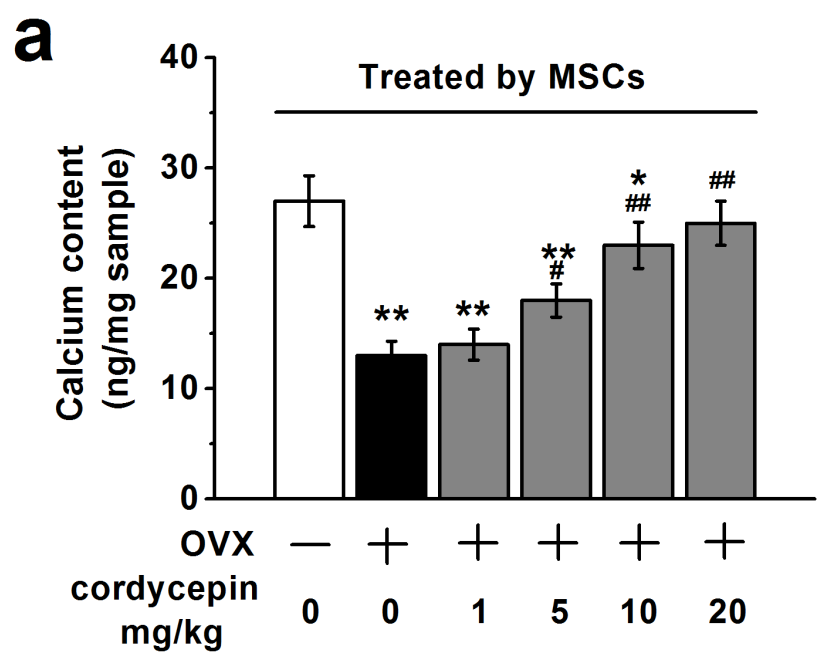

\section{DISCUSSION}

Many reports have provided evidence that there is a link between oxidative stress, bone formation and osteogenic differentiation. It has been shown that oxidative stress impairs osteogenic differentiation of murine pre-osteoblastic and bone marrow-derived stromal cell lines [3]. Exogenous addition of $\mathrm{H}_{2} \mathrm{O}_{2}(125-500 \mu \mathrm{M})$ to human BM-MSCs reduced Alp activity, a marker for osteogenic differentiation and abolishes osteogenesis in osteoblast progenitors [21, 22]. Additionally, NOX4 (NADPH oxidase 4) knockout mice exhibit higher bone density. NOX4 promotes the transformation of osteoblasts to osteoclasts, thus limiting bone mass [23]. Consistent with these findings, we observed that exposure to $\mathrm{H}_{2} \mathrm{O}_{2}$ (0.2 $\mathrm{mM}$ or higher concentration) increased intracellular ROS levels and reduced ALP activity, calcium content as well as Runx2 mRNA levels, suggesting that oxidative stress inhibits osteogenesis in these BM-MSCs.

It has been reported that cordycepin can protect against estrogen deficiency-induced osteoporosis in OVX rats [24]. Another study showed that cordycepin can prevent hearts from ischemia/reperfusion injury via activation of Akt/GSK-3b/p70S6K pathways and HO-1 expression, an antioxidant enzyme, in rat hearts [15]. Additionally, cordycepin has been reported to exert neuroprotective effects by inhibiting glutamate-induced oxidative apoptosis in HT22 cells [14]. Our results showed that co-treatment with cordycepin significantly promoted osteogenesis by reducing production of ROS induced by $\mathrm{H}_{2} \mathrm{O}_{2}$ exposure in BM-MSCs. However, treatment with cordycepin alone did not have effects, demonstrating that cordycepin can exert osteoprotective effects in the presence of excess oxidative stress.

b

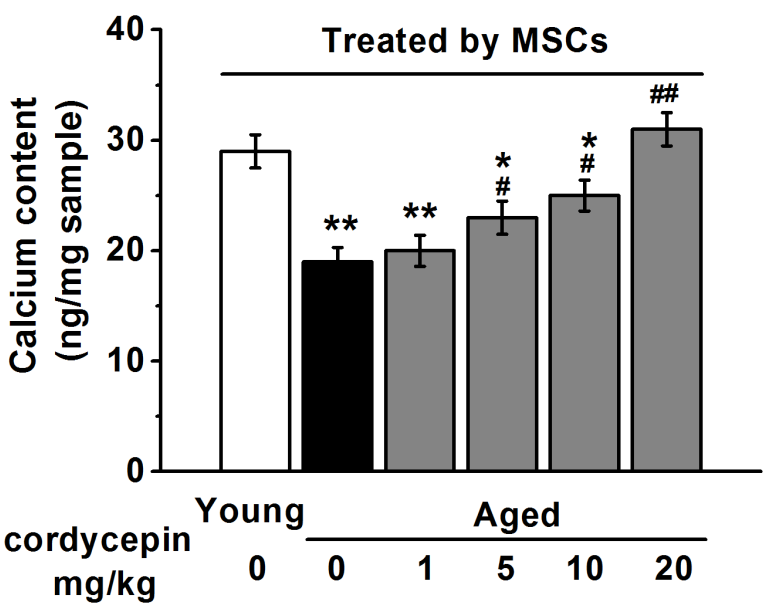

Figure 7: Effects of cordycepin $(1,5,10$ and $20 \mathrm{mg} / \mathrm{kg})$ on in vivo osteogenic differentiation of human BM-MSCs in ovariectomized a. and aged animal models $\mathbf{b}$. The calcium contents in the implantation specimens were determined by spectrophotometry using Methylxylene blue method in the experimental groups (all $n=8)$. Data were shown as mean \pm S.E.M. $* p<0.05$ and $* * p<0.01$ versus control or non-treated young mice, $\# p<0.05$ and \#\#p<0.01 versus OVX group or non-treated aged mice. 
Osteoblasts and osteoclasts are responsible for bone formation and bone resorption, respectively, the two critical processes involved in bone remodeling. $O P G$ inhibits osteoclast differentiation by binding to $R A N K L$ (receptor activator of nuclear factor-B ligand), which is critical for the maturation and activity of osteoclasts [25]. Several studies have shown that ROS can increase expression of RANKL in osteoblasts [21]. An increase in $O P G ; R A N K L$ ratio favors bone formation whereas a decrease in this ratio favors bone resorption [20]. We observed that cordycepin significantly increased $O P N$ expression but reversed the $\mathrm{H}_{2} \mathrm{O}_{2}$ induced $R A N K L$ upregulation to control level. Moreover, cordycepin upregulated the expression of $O P G$ and Collagen I, two osteogenesis marker genes. These results indicate that cordycepin can inhibit osteoclastogenesis and promote osteogenic differentiation by increasing or decreasing related genes' expression.

Current studies support that Wnt signaling pathway plays important roles in osteogenic differentiation and bone formation [26, 27]. Activation of canonical Wnt signaling results in higher bone density whereas disruption of its activation impairs osteogenesis [18, 19]. Wnt signaling pathway contributes to osteogenesis primarily through activation of $\beta$-catenin, which induces essential signals for osteogenic initiation and reduces the expression of $\mathrm{C} / \mathrm{EBPa}$ and PPARg, key suppressors of osteogenesis [2]. In this study, treatment with cordycepin

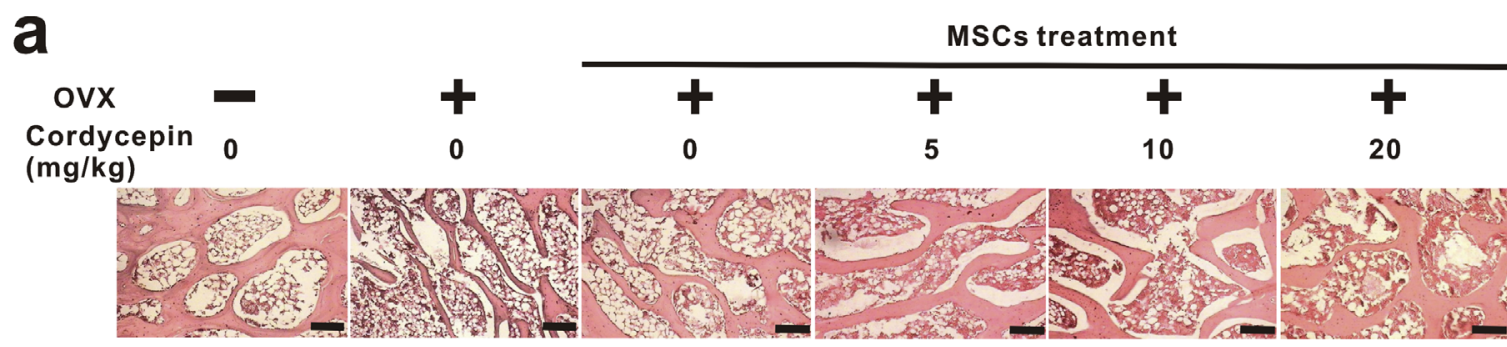

b
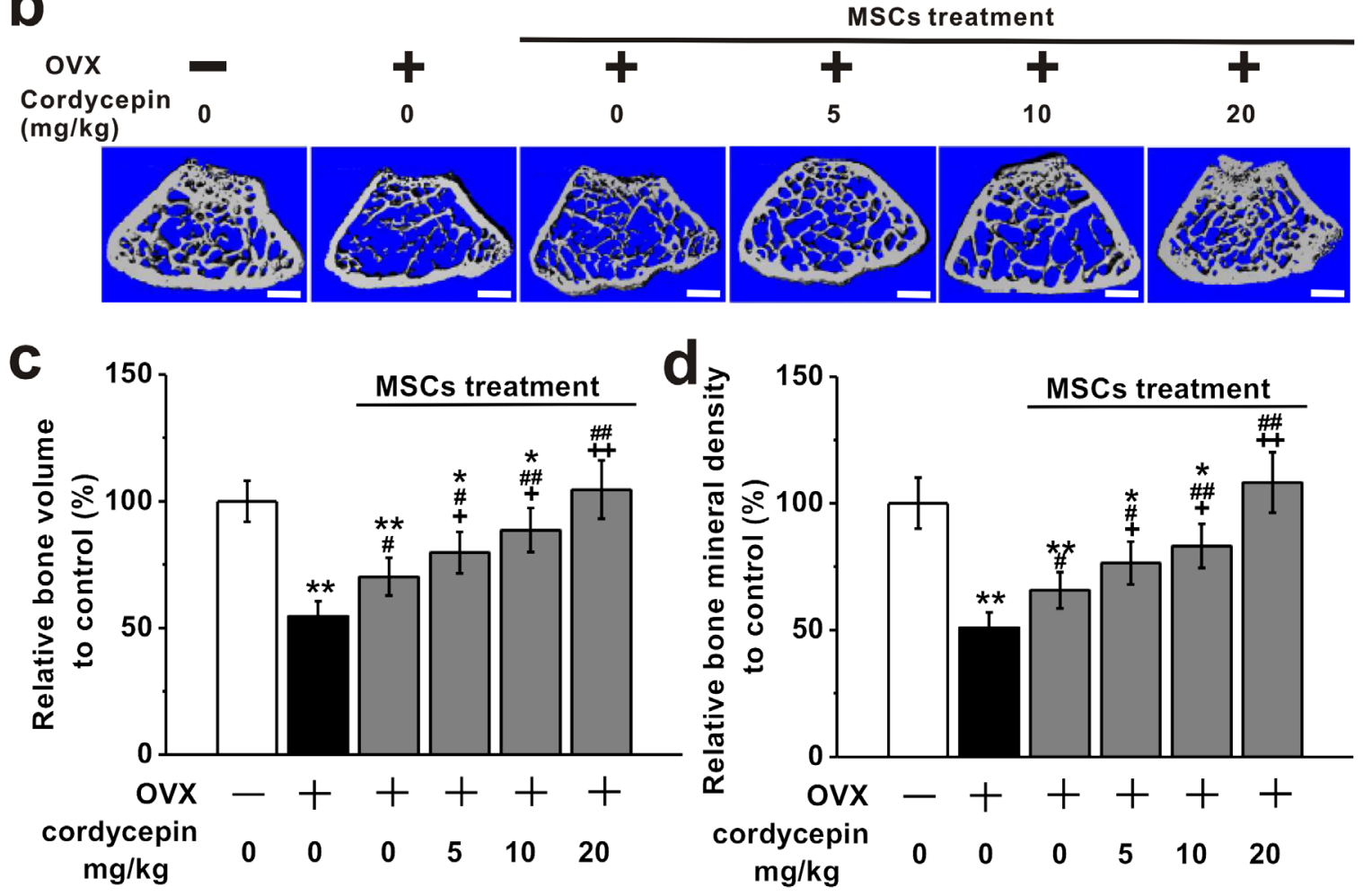

Figure 8: Effects of cordycepin $(5,10$ and $20 \mathrm{mg} / \mathrm{kg})$ on bone loss in ovariectomized animal model when treated with MSCs. The animals were examined at 8 weeks after ovariectomy. a. H\&E staining of the femoral trabecular micro architecture in the experimental groups. Scale bar, $100 \mu \mathrm{m}$. b. Representative images of reconstructed micro-computed tomography of the femur in the experimental groups. Scale bar, $400 \mu \mathrm{m}$. Analysis of relative bone volume c. and bone mineral density d. in the experimental animals. Data were shown as mean \pm S.E.M. ${ }^{*} p<0.05$ and ${ }^{* *} p<0.01$ versus control mice, $\# p<0.05$ and $\# \# p<0.01$ versus OVX mice, $+p<0.05$ and $++p<0.01$ versus OVX and MSC treated mice. 
increased protein expression of $\beta$-catenin and cyclin D1, another key target gene of Wnt pathway [28]. Additionally, supplementation of DDK1, a Wnt pathway inhibitor, reversed osteoprotective effects of cordycepin. These results suggest that Wnt- $\beta$-catenin signaling pathway may be involved in cordycepin promoted osteogenesis of BMMSCs.

Growing evidence supports that oxidative stress is one of the main contributing factors to decline in cellular functions due to aging [29]. The increased oxidative stress has been associated with the pathogenesis of agerelated bone loss in humans and mice [30]. Importantly, cordycepin has recently been shown to mitigate agerelated oxidative stress by enhancing antioxidant capacity in rats [10]. We observed similar osteoprotective effects of cordycepin in both OVS and aged mouse models in our study, suggesting the potential of cordycepin for future clinical applications.

In conclusion, our study demonstrated the osteoprotective effects of cordycepin against $\mathrm{H}_{2} \mathrm{O}_{2}$ induced inhibition of osteogenesis by reducing oxidative stress both in vitro and in vivo. Cordycepin exerts this protective effects partially by increasing or decreasing expression of osteogenic and osteoclastogenesis marker genes as well as activating Wnt pathway activity. Cordycepin may represent a valuable regenerative medicine or a therapeutic reagent for treatment of age-related osteoporosis in humans.

\section{MATERIALS AND METHODS}

\section{Isolation and culture of human BM-MSC}

Bone marrow samples were obtained from 4 fetuses (median gestational age, 1315 weeks; range, 1112 to 1413). Single-cell suspensions of fetal bone marrow were prepared by flushing the bone marrow cells out of the humeri and femurs using a syringe and 22-gauge needle DMEM media supplemented with $10 \%$ fetal bovine serum (FBS) (Gibco, Grand Island, USA)penicillin (100 U/mL) (Sigma, St. Louisa, USA), and streptomycin $(100 \mu \mathrm{g} /$ $\mathrm{mL}$ ) (Sigma, St. Louisa, USA),. All cultured cells were incubated in a humidified atmosphere at $37^{\circ} \mathrm{C}$ and at $5 \%$ $\mathrm{CO}_{2}$. To expand the cells through successive passages, they were plated at $10^{4}$ cells $/ \mathrm{cm}^{2}$, grown to near confluence, and harvested with the same protocol. To isolate individual colonies, nucleated cells were plated in a $100-\mathrm{mm}$ dish at a density of $12000 / \mathrm{cm}^{2}$ and were collected by cloning cylinders (Sigma, St. Louisa, USA) and expanded. Cultured fetal MSCs were recloned by single-cell sorting using FACS Vantage (Becton Dickinson, Franklin Lakes, USA).

\section{Drugs}

Cordycepin with 98\% purification was obtained following the extraction and separation using a column chromatographic method [31].

\section{Induction of osteoblast differentiation}

Approximately $1 \times 10^{4}$ cells BM-MSCs were placed in a $35 \mathrm{~mm}$ culture dish (Corning, Corning, USA). Osteoblast differentiation was induced by culturing cells in osteogenic medium composing of DMEM-high glucose, 10\% FBS (Hyclone, Logan, USA), 100-100 $\mu \mathrm{g} /$ $\mathrm{mL}$ penicillin-streptomycin (Gibco, Grand Island, USA), $50 \mu \mathrm{g} / \mathrm{mL}$ L-ascorbic acid-2-phosphate (Sigma, St. Louisa, USA), L-glutamine (Sigma, St. Louisa, USA), 10-7 M dexamethasone (Sigma, St. Louisa, USA), and $10 \mathrm{mM}$ $\beta$-glycerophosphate (Sigma, St. Louisa, USA) for 21 days. Media was changed every 3 days.

\section{Flow cytometry}

BM-MSC cells were trypsinized and stained with anti-CD34-fluorescein isothiocyanate (FITC), CD45FITC, CD73-FITC, CD90-FITC, CD105 (endoglin)FITC, and were analyzed by FACScalibur flow cytometry (Becton Dickinson, Franklin Lakes, USA).

\section{Cell viability assay}

For this experiment, the BM-MSC cells were treated with different concentration of $\mathrm{H}_{2} \mathrm{O}_{2}(0.1,0.2,0.5,1$ and $2 \mathrm{mM}$ ) for $24 \mathrm{~h}$. Different concentrations of cordycepin $(1,5,10,20,40$ and $80 \mu \mathrm{g} / \mathrm{mL})$ were supplemented in the culture medium during the whole culture. MTT assays were performed to measure cell survival. The absorbances of all of the wells were recorded using a micro-plate reader at $492 \mathrm{~nm}$ wavelength. The cell survival of the control group, which was not exposed to either $\mathrm{H}_{2} \mathrm{O}_{2}$ or cordycepin, was defined as $100 \%$.

\section{Alkaline phosphatase (ALP) activity assay}

BM-MSC cells $\left(3 \times 10^{3}\right.$ cells/well $)$ were incubated in a 96-well plate overnight and treated with different concentrations of $\mathrm{H}_{2} \mathrm{O}_{2}$ for $24 \mathrm{~h}$ and/or the cordycepin in the medium for the whole duration of culture. ALP activity was measured in total cell lysates after homogenization in a buffer containing $1 \mathrm{mM}$ Tris- $\mathrm{HCl}$ ( $\mathrm{pH} 8.8), 0.5 \%$ Triton $\mathrm{X}-100,10 \mathrm{mM} \mathrm{Mg}^{2+}$, and $5 \mathrm{mM}$ p-nitrophenylphosphate as substrates. The absorbance was read at $405 \mathrm{~nm}$. The ALP activity was normalized to total protein, which was measured using the Bradford protein assay. The assay was 
performed 8 days after cell culture.

\section{Calcium accumulation assay}

To evaluate osteogenic differentiation, the calcium content in BM-MSCs was measured using Calcium Assay 16 days after cell culture (Genzyme Diagnostics, Charlottetown, PE, Canada) according to manufacturer's instructions. Briefly, samples were added with $1 \mathrm{M}$ acetic acid and placed on a vortex overnight at $4{ }^{\circ} \mathrm{C}$ to extract the calcium from the mineralized matrix. In a 96-well clear polycarbonate plate, $15 \mu \mathrm{L}$ cell extract was mixed with $150 \mu \mathrm{L}$ Calcium Assay reagent and incubated for $30 \mathrm{~s}$ at room temperature. The absorbance at $650 \mathrm{~nm}$ was determined using a SpectraMAX 250 microplate reader. The samples were measured in triplicate and compared to the calcium calibration curve. The calcium content was normalized by cell protein amount and expressed as relative calcium content normalized to control sample.

\section{Intracellular ROS levels determination}

ROS level was measured using fluorescence associated oxidation of dichlorodihydrofluorescein (DCFH) to dichlorofluorescein (DCF; [32]). After treated with $\mathrm{H}_{2} \mathrm{O}_{2}$ and/or cordycepin, cells cultured on $8 \times 8$ $\mathrm{mm}$ square glass coverslips were rinsed with ice-cold phosphate-buffered saline (PBS) and then incubated in $10 \mu \mathrm{M}$ DCFH-DA (Sigma, St. Louisa, USA) for $15 \mathrm{~min}$ at $37^{\circ} \mathrm{C}$ in the dark. Fluorescence was measured using confocal microscope (Zeiss LSM510) at excitation and emission wavelengths of 495 and $535 \mathrm{~nm}$ for DCF fluorescence. In average, ten BM-MSC cells/ microscope field were quantified in three to four separate cultures per treatment condition. Zeiss confocal microscope was used to visualize DCF fluorescence. ImageJ was used to quantify fluorescence intensity.

\section{Real time-PCR}

Total RNA was isolated from BM-MSCs treated with $\mathrm{H}_{2} \mathrm{O}_{2}$ and/or cordycepin, using TRIZOL reagent (Invitrogen, Carlsbad, USA). $1 \mu \mathrm{g}$ RNA was initially reverse-transcribed into cDNA using the SuperScript ${ }^{\mathrm{TM}}$ III First-Strand Synthesis System (Invitrogen, Carlsbad, USA). Real-time quantitative PCR reactions were set up in triplicate with Ssofast Master Mix (Biorad) and run on a LightCycler® 480 (Roche, New Yok, USA). The genes osteopontin (OPN) and collagen I were measured to assess osteogenic differentiation. For osteoclast differentiation, osteoprotegerin (OPG) and receptor activator of nuclear factor- $\kappa B$ ligand (RANKL) were measured. The housekeeping gene, glyceraldehyde-3-phosphate dehydrogenase (GAPDH), was used as an endogenous reference gene. Primers used in the experiment were as follows:

$O P N, \quad 5, \quad$-GAGACCCTTCCAAGTAAGTCCA (forward)

and 5, -GATGTCCTCGTCTGTAGCATCA

(reverse);

Collagen I, 5' - ACAGCCGCTTCACCTACAGC

(forward)

and 5 , -TGCACTTTTGGTTTTTGGTCAT

(reverse);

OPG, 5'-TGCTGTTCCTACAAAGTTTACG

(forward)

and 5'-CTTTGAGTGCTTTAGTGCGTG (reverse);

$R A N K L, \quad 5$ '- CCAGCATCAAAATCCCAAGT

(forward)

and 5 -CCCCAAAGTATGTTGCATCCTG

(reverse);

Runx2, 5' - TCTTAGAACAAATTCTGCCCTTT

(forward)

and 5' - TGCTTTGGTCTTGAAATCACA (reverse); Axin2, 5'-CTCCTTGGAGGCAAGAGC (forward) and 5'-GGCCACGCAGCACCGCTG (reverse); c-MYC, 5'-TGGATTTTTTTTCGGGTAGTGG

(forward)

and 5'-GTCGTAGTCGAGGTCATAGTTCC

(reverse);

GAPDH, 5'- GAAGGTGAAGGTCGGAGTC

(forward)

and 5' -GAGATGGTGATGGGATTTC(reverse).

\section{Nuclear fraction and western blot}

Cell lysate from the tissues was extracted using RIPA lysis buffer (Santa Cruz, Dallas, USA) containing $1 \%$ protease inhibitor cocktail. For $\beta$-catenin analysis in the nucleus, cells were harvested and subjected to nuclear and cytoplasmic fractionation using NE-PER Nuclear and Cytoplasmic Extraction Reagents (Thermo Scientific, USA) according to the instruction. Briefly, cells were washed with PBS, centrifuged down and left dry. Reagents CER I and CER II were added followed by centrifugation. Supernatant that contains cytoplasmic extract was discarded. Reagent NER was added to dissolve the pallet, which contains nuclear extract. Extracts were subjected to further western blot analysis or stored at $-80{ }^{\circ} \mathrm{C}$ for further use. For electrophoresis, a total of $30 \mu \mathrm{g}$ of protein were loaded onto a $12 \%$ SDSPAGE gel. After transfer, membranes were blocked in 5 $\%$ nonfat milk in Tris-buffered saline (TBS)/Tween-20 $(0.2 \%)$ overnight at $4{ }^{\circ} \mathrm{C}$ and then incubated with rabbit polyclonal antibodies against $\beta$-catenin, cyclin-D1, H3 and GAPDH diluted in TBS/T for $1 \mathrm{~h}$ at $37^{\circ} \mathrm{C}$. After three washes in TBS/T, the membranes were incubated with anti-rabbit $\mathrm{IgG}$ conjugated to horseradish peroxidase (Zhongshan Golden Bridge Biotechnology, Beijing, China) at a dilution of 1:2,000 in $\mathrm{TBS} / \mathrm{T}$ for $40 \mathrm{~min}$ at 
$37^{\circ} \mathrm{C}$. The immunoreactive bands were visualized with an enhanced chemiluminescence kit (Zhongshan Golden Bridge Biotechnology, Beijing China).

\section{Animal experiments}

Ovariectomized (OVX) mouse model was established as described before [33]. Briefly, forty eight 8 -week-old, BALB/c female mice with similar weight were obtained from Shanghai Jiaotong University. After adaptation to the laboratory environment (a well-ventilated controlled room at $20^{\circ} \mathrm{C}$ on a 12 -h light/dark cycle; the animals were given free access to water and food) for 1 week, the mice experienced sham-operation $(n=10)$ or were surgically ovariectomized $(n=40)$ under anesthesia using pentobarbital sodium $(50 \mathrm{mg} / \mathrm{kg}$ body weight, i.p. $)$. The ovariectomy operation was performed according to Steven K. Boyd's procedure [34]. For the aged animal model, eight young $\mathrm{BALB} / \mathrm{c}$ female mice (8-weekold) and forty old BALB/c female mice (one-year-old) were obtained from Shanghai Jiaotong University and acclimatized to the facility for at least 1 week prior to the experiment. For in vivo osteogenesis experiments (Figure 7 ) in both mouse models, mice were divided into control group $(n=8)$ or cordycepin treated groups (4 groups, $\mathrm{n}=8$ for each group). Experimental mice received i.p. injection of 1,5,10 and $20 \mathrm{mg} / \mathrm{kg}$ of cordycepin daily for four months. For the experiments in Figure 8, the animals received the different concentrations of cordycepin daily until the end of experiment ( 8 weeks). This study was carried out in strict accordance with the recommendations in the Guide for the Care and Use of Laboratory Animals of the National Institutes of Health (Guide for the Care and Use of Laboratory Animals, 9th edition). The protocol was approved by the Committee on the Ethics of Animal Experiments of Shanghai Jiao Tong University Affiliated Sixth People's Hospital. All surgery was performed under sodium pentobarbital anesthesia, and all efforts were made to minimize suffering.

\section{MDA, GSH measurement}

The activity of malondialdehyde (MDA) in whole blood samples from OVX and aged mouse models receiving i.p. injections of $1,5,10$ and $20 \mathrm{mg} / \mathrm{kg}$ of cordycepin was determined using a lipid peroxidation MDA assay kit according to the manufacturer's instructions. The binding of thiobarbituric acid to MDA results in a chromogenic complex that can be detected at $532 \mathrm{~nm}$ using a spectrophotometer. The activity of Glutathione (GSH) was determined using the GSH assay kit. The GSH activity was determined by the reaction of GSH with 5.50-dithiobis-2-nitrobenzoic acid (DTNB) to produce a product that could be measured using a spectrophotometer at $412 \mathrm{~nm}$.

\section{In vivo osteogenesis of MSCs under cordycepin treatment}

A total of $1 \times 10^{6}$ MSCs was injected under the skin of the mice. After anesthesia with subcutaneous injection of a combination of $0.5 \mu \mathrm{L} / \mathrm{g}$ of tiletmine-zolazepam and $0.5 \mu \mathrm{L} / \mathrm{g}$ xylazine, small skin incisions were made and subcutaneous pouches were formed in the back of experimental animals, into which the MSCs were injected. After that, the skin incisions were closed with 4-0 nylons. For the cordycepin treated group, the mice were treated with cordycepin $(1,5,10$ and $20 \mathrm{mg} / \mathrm{kg}$ ) during the whole experiment. To measure the calcium contents of in vivo implanted specimens, each sample was deparaffinized, dried at $95^{\circ} \mathrm{C}$ for $1 \mathrm{~h}$, weighed and decalcified in $1 \mathrm{~mL}$ of Calci-clear Rapid. The calcium content of the supernatants was determined by spectrophotometry using Methylxylene blue method.

\section{Hematoxylin-eosin $(\mathrm{H} \& \mathrm{E})$ staining}

The femurs were cleaned and placed in decalcifying solution and $10 \%$ formic acid in PBS for $24 \mathrm{~h}$, then dehydreated in $95 \%$ ethanol and embedded in paraffin. The sections were cut and stained with H\&E and examined by light microscopy.

\section{Micro-computed tomography (micro-CT) examination}

The femurs were evaluated by micro-CT (Scanco Medical AG, Switzerland). The scanning parameters were set at $50 \mathrm{kV}, 100 \mu \mathrm{A}$. Images were reconstructed and analyzed with Scanco Medical software. Fractional bone volume is determined as bone volume per tissue volume, while bone mineral density was calculated.

\section{Statistical analysis}

Results are expressed as mean \pm SEM, and statistical comparisons were performed using the Student $t$ test. Statistical difference was considered to be significant only if $P<0.05$.

\section{ACKNOWLEDGMENTS}

None.

\section{GRANT SUPPORT}

This work was supported by the National 
Natural Science Foundation of China (No. 81472110); Shanghai Municipal Natural Science Foundation (No. 14ZR1431800), Research Foundation of Shanghai Jiaotong University School of Medicine (No. 13XJ10065), the Interdisciplinary Program of Shanghai Jiao Tong University (No. YG2014MS22), Three-year Action Plan (2014-2016) of Shanghai's Development Acceleration in Traditional Chinese Medicine (No. ZY3-CCCX-3-3044).

\section{CONFLICTS OF INTEREST}

The authors declare that they have no conflicts of interest to disclose.

\section{REFERENCES}

1. Sanchez-Rodriguez MA, Ruiz-Ramos M, Correa-Munoz E and Mendoza-Nunez VM. Oxidative stress as a risk factor for osteoporosis in elderly Mexicans as characterized by antioxidant enzymes. BMC musculoskeletal disorders. 2007; 8:124.

2. Atashi F, Modarressi A and Pepper MS. The role of reactive oxygen species in mesenchymal stem cell adipogenic and osteogenic differentiation: a review. Stem cells and development. 2015; 24:1150-1163.

3. Mody N, Parhami F, Sarafian TA and Demer LL. Oxidative stress modulates osteoblastic differentiation of vascular and bone cells. Free radical biology \& medicine. 2001; 31:509519.

4. Basu S, Michaelsson K, Olofsson H, Johansson S and Melhus H. Association between oxidative stress and bone mineral density. Biochemical and biophysical research communications. 2001; 288:275-279.

5. Shouhed D, Kha HT, Richardson JA, Amantea CM, Hahn TJ and Parhami F. Osteogenic oxysterols inhibit the adverse effects of oxidative stress on osteogenic differentiation of marrow stromal cells. Journal of cellular biochemistry. 2005; 95:1276-1283.

6. Gerson SL. Mesenchymal stem cells: no longer second class marrow citizens. Nature medicine. 1999; 5:262-264.

7. Pontikoglou C, Deschaseaux F, Sensebe L and Papadaki HA. Bone marrow mesenchymal stem cells: biological properties and their role in hematopoiesis and hematopoietic stem cell transplantation. Stem cell reviews. 2011; 7:569589.

8. Horwitz EM, Prockop DJ, Fitzpatrick LA, Koo WW, Gordon PL, Neel M, Sussman M, Orchard P, Marx JC, Pyeritz RE and Brenner MK. Transplantability and therapeutic effects of bone marrow-derived mesenchymal cells in children with osteogenesis imperfecta. Nature medicine. 1999; 5:309-313.

9. Knight MN and Hankenson KD. Mesenchymal Stem Cells in Bone Regeneration. Advances in wound care. 2013; 2:306-316.
10. Ramesh T, Yoo SK, Kim SW, Hwang SY, Sohn SH, Kim IW and Kim SK. Cordycepin (3'-deoxyadenosine) attenuates age-related oxidative stress and ameliorates antioxidant capacity in rats. Experimental gerontology. 2012; 47:979-987.

11. Cheng Z, He W, Zhou X, Lv Q, Xu X, Yang S, Zhao C and Guo L. Cordycepin protects against cerebral ischemia/ reperfusion injury in vivo and in vitro. European journal of pharmacology. 2011; 664:20-28.

12. Feng X. Regulatory roles and molecular signaling of TNF family members in osteoclasts. Gene. 2005; 350:1-13.

13. Jeong JW, Jin CY, Park C, Hong SH, Kim GY, Jeong YK, Lee JD, Yoo YH and Choi YH. Induction of apoptosis by cordycepin via reactive oxygen species generation in human leukemia cells. Toxicology in vitro : an international journal published in association with BIBRA. 2011; 25:817824.

14. Jin ML, Park SY, Kim YH, Oh JI, Lee SJ and Park G. The neuroprotective effects of cordycepin inhibit glutamateinduced oxidative and ER stress-associated apoptosis in hippocampal HT22 cells. Neurotoxicology. 2014; 41:102111.

15. Park ES, Kang DH, Yang MK, Kang JC, Jang YC, Park JS, Kim SK and Shin HS. Cordycepin, 3'-deoxyadenosine, prevents rat hearts from ischemia/reperfusion injury via activation of Akt/GSK-3beta/p70S6K signaling pathway and HO-1 expression. Cardiovascular toxicology. 2014; 14:1-9.

16. Logan CY and Nusse R. The Wnt signaling pathway in development and disease. Annual review of cell and developmental biology. 2004; 20:781-810.

17. Clevers H. Wnt/beta-catenin signaling in development and disease. Cell. 2006; 127:469-480.

18. Babij P, Zhao W, Small C, Kharode Y, Yaworsky PJ, Bouxsein ML, Reddy PS, Bodine PV, Robinson JA, Bhat B, Marzolf J, Moran RA and Bex F. High bone mass in mice expressing a mutant LRP5 gene. Journal of bone and mineral research : the official journal of the American Society for Bone and Mineral Research. 2003; 18:960-974.

19. James AW. Review of Signaling Pathways Governing MSC Osteogenic and Adipogenic Differentiation. Scientifica. 2013; 2013:684736.

20. Liu M, Li Y and Yang ST. Effects of naringin on the proliferation and osteogenic differentiation of human amniotic fluid-derived stem cells. Journal of tissue engineering and regenerative medicine. 2014.

21. Bai XC, Lu D, Liu AL, Zhang ZM, Li XM, Zou ZP, Zeng WS, Cheng BL and Luo SQ. Reactive oxygen species stimulates receptor activator of NF-kappaB ligand expression in osteoblast. The Journal of biological chemistry. 2005; 280:17497-17506.

22. Almeida M, Han L, Martin-Millan M, Plotkin LI, Stewart SA, Roberson PK, Kousteni S, O’Brien CA, Bellido T, Parfitt AM, Weinstein RS, Jilka RL and Manolagas SC. 
Skeletal involution by age-associated oxidative stress and its acceleration by loss of sex steroids. The Journal of biological chemistry. 2007; 282:27285-27297.

23. Goettsch C, Babelova A, Trummer O, Erben RG, Rauner M, Rammelt S, Weissmann N, Weinberger V, Benkhoff S, Kampschulte M, Obermayer-Pietsch B, Hofbauer LC, Brandes RP and Schroder K. NADPH oxidase 4 limits bone mass by promoting osteoclastogenesis. The Journal of clinical investigation. 2013; 123:4731-4738.

24. Zhang DW, Deng H, Qi W, Zhao GY and Cao XR. Osteoprotective effect of cordycepin on estrogen deficiencyinduced osteoporosis in vitro and in vivo. BioMed research international. 2015; 2015:423869.

25. Boyce BF and Xing L. Functions of RANKL/RANK/OPG in bone modeling and remodeling. Archives of biochemistry and biophysics. 2008; 473:139-146.

26. Day TF, Guo X, Garrett-Beal L and Yang Y. Wnt/betacatenin signaling in mesenchymal progenitors controls osteoblast and chondrocyte differentiation during vertebrate skeletogenesis. Developmental cell. 2005; 8:739-750.

27. Huang W, Yang S, Shao J and Li YP. Signaling and transcriptional regulation in osteoblast commitment and differentiation. Frontiers in bioscience : a journal and virtual library. 2007; 12:3068-3092.

28. Shtutman M, Zhurinsky J, Simcha I, Albanese C, D'Amico $\mathrm{M}$, Pestell R and Ben-Ze'ev A. The cyclin D1 gene is a target of the beta-catenin/LEF-1 pathway. Proceedings of the National Academy of Sciences of the United States of America. 1999; 96:5522-5527.

29. Beckman KB and Ames BN. The free radical theory of aging matures. Physiological reviews. 1998; 78:547-581.

30. Almeida M, Han L, Martin-Millan M, O'Brien CA and Manolagas SC. Oxidative stress antagonizes Wnt signaling in osteoblast precursors by diverting beta-catenin from $\mathrm{T}$ cell factor- to forkhead box O-mediated transcription. The Journal of biological chemistry. 2007; 282:27298-27305.

31. Ni H, Zhou XH, Li HH and Huang WF. Column chromatographic extraction and preparation of cordycepin from Cordyceps militaris waster medium. Journal of chromatography B, Analytical technologies in the biomedical and life sciences. 2009; 877:2135-2141.

32. Lin HH, Li WW, Lee YC and Chu ST. Apoptosis induced by uterine $24 \mathrm{p} 3$ protein in endometrial carcinoma cell line. Toxicology. 2007; 234:203-215.

33. Huang Q, Gao B, Jie Q, Wei BY, Fan J, Zhang HY, Zhang JK, Li XJ, Shi J, Luo ZJ, Yang L and Liu J. Ginsenoside$\mathrm{Rb} 2$ displays anti-osteoporosis effects through reducing oxidative damage and bone-resorbing cytokines during osteogenesis. Bone. 2014; 66:306-314.

34. Boyd SK, Davison P, Muller R and Gasser JA. Monitoring individual morphological changes over time in ovariectomized rats by in vivo micro-computed tomography. Bone. 2006; 39:854-862. 